\title{
Harlequin Baby with Mild Skin Disorder: Two Years Follow Up
}

\section{Ismail Biyik* and Fatih Keskin \\ Department of Gynecology, Karacabey State Hospital, Turkey}

Submission:March 16, 2018; Published: April 09, 2018

*Corresponding author: Ismail Biyik, Departmnet of Gynecology, Karacabey State Hospital, Karacabey State Hospital, 16700, Bursa/Turkey, Tel: +(90) 5327867031; Email: dribiyik@hotmail.com

\section{Abstract}

Harlequin ichthyosis is a member of nonsyndromic inherited ichthyosis. Neonates born with HI have generally poor prognosis. In this case report, a case of harlequin delivered at the 37th gestational week was presented. Antibiotic prophylaxis was given to the baby with emoillent creams in the newborn period. The boy is now 2.5 years old and does not have a disease other than scaly skin. The child continues to receive emoillent cream treatment. However HI has a high mortality rate during the newborn period, we believe that early antibiotic prophylaxis and the application of softening creams may prevent mortality.

\section{Introduction}

The ichthyoses is a keratinization disorder of skin. These disorders are heterogeneous group. The great majority of ichthyoses are inherited. Harlequin Ichthyosis (HI) is a member of nonsyndromic inherited ichthyosis. HI is a rare, severe form of congenital ichthyosis, which may be fatal [1]. Newborns with HI present with thick, fissured armor-plate hyperkeratosis, severe ectropion, eclabium, and malformation of the auricle. Early complications result from infection due to fissuring of the hyperkeratotic plates. Prior reports suggest that the mortality rate in the neonatal period is approximately 50 percent. Many infants with HI die shortly after birth. Fortunately improved neonatal intensive care and early treatment with oral retinoids may improve survival [2].

\section{Case report}

23 years old parous pregnant was admitted to the hospital with complaints of premature membrane rupture at 37 th gestational week. There was a healthy baby and early pregnancy loss in obstetric history. There was a healthy baby and early pregnancy loss in obstetric history. The woman was followed up with regular pregnancy. Sonographically there was no anomaly detected. $2800 \mathrm{~g}$ male baby born with vaginal delivery. His first and fifth Apgar scores were 8 and 10, respectively. It was seen that the newborn was a white layer covering the whole body of the baby separated by red cracks on the examination (Figure 1). Ectropion and eclabium were seen on the face. Due to excess of scales around the mouth gave the typical fish-like appearance.
The family history was taken and pedigree analysis was done. There was no history of dermatological-related disorder or any other genetic disease. Emollients, lubricants and antibiotic pomades were applied on baby's skin. Prophylactic antibiotics were given to prevent sepsis The baby was referered tertiary hospital. When the child was examined at the age of 2.5 , it was seen that there was no disease other than a scaly skin (Figure 2). The child still continues to receive emoillent cream treatment and development is normal. He use emoillent cream regularly. He has not limb contracture.

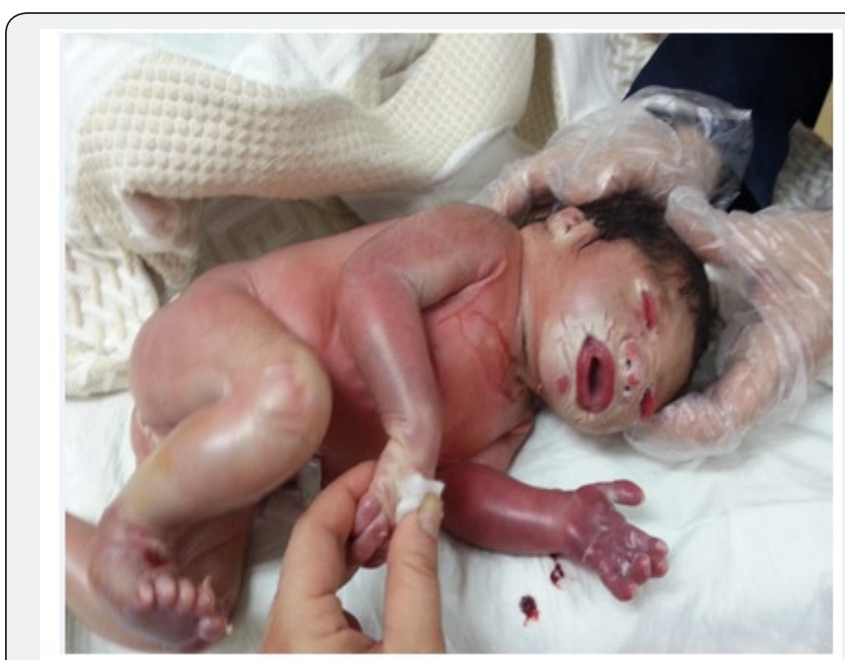

Figure 1: It was seen that the newborn was a white layer covering the whole body of the baby separated by red cracks on the examination. 


\section{Global Journal of Reproductive Medicine}

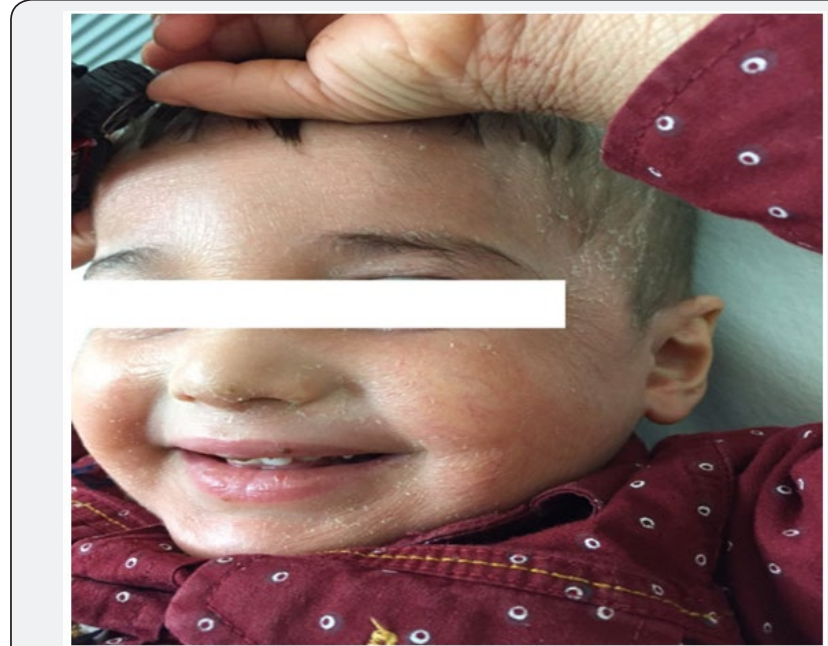

Figure 2: It was seen that there was no disease other than a scaly skin.

\section{Discussion}

Neonates born with HI have generally poor prognosis. Perinatal death is very common because of sepsis or respiratory failure. In this case prophylactic antibiotics were given to prevent skin and other infections. Emolillent cream were used for softening face and body skin. Breastfeeding was successful in neonatal period with emollient treatment. Early breastfeeding prevented malnutrition and infections. Rajpopat et al. Reported a survival rate of $56 \%$. In that study 16 of $45 \mathrm{HI}$ cases survived for 7 years or more and the longest surviving case reached 25 years [2]. Pejaver et al. [3] reported survial of a baby with HI is 22 months [3]. There are some reports indicating a 50\% survival rate with advanced intensive care [4]. Mithwani et al reported that survival 7 years of a male baby with HI is 7 years [5]. Ugurel et al reported a case with $\mathrm{HI}$ was survive only 1 week [6]. In the literature, there were reported high mortality rates in HI cases. In our case, the baby is 2.5 years old and healthy except the scaly skin.

\section{Conclusion}

However $\mathrm{HI}$ has a high mortality rate during the newborn period, we believe that early antibiotic prophylaxis and the application of softening creams may prevent mortality.

\section{Note}

The pictures and information belonging to the child were shared with the written consent of the family.

\section{References}

1. Kelsell DP, Norgett EE, Unsworth H, Teh MT, Cullup T, et al. (2005) Mutations in ABCA12 underlie the severe congenital skin disease harlequin ichthyosis. Am J Hum Genet 76(5): 794-803.

2. Rajpopat S, Moss C, Mellerio J, Vahlquist A, Gånemo A, et al. (2011) Harlequin Ichthyosis: a review of clinical and molecular findings in 45 cases. Arch Dermatol 147(6): 681-686.

3. Pejaver RK, Prasad RS, Garg AK, Jelly A, Shawkat S (1998) Etrinate in the management of harlequin siblings. Indian J Pediatr 65(2): 320-323.

4. Follmann J, Macchiella D, Whybra C, Mildenberger E, Poarangan C, et al. (2013) Identification of novel mutations in the ABCA12 gene, c.1857delA and c.5653-5655delTAT, causing harlequin ichthyosis. Gene 531(2): 510-513.

5. Mithwani AA, Hashmi A, Shahnawaz S, Al Ghamdi Y (2014) Harlequin ichthyosis: a case report of prolonged survival. BMJ Case Rep.

6. Ugurel V, Turhan E, Aslan MM (2016) A rare case of harlequin ichthyosis with isolated oligohydramnios and elevated serum AFP level. Medical Journal of Istanbul Kanuni Sultan Suleyman 8(2): 186-188.

Your next submission with Juniper Publishers
will reach you the below assets
- Quality Editorial service
- Swift Peer Review
- Reprints availability
- E-prints Service
- Manuscript Podcast for convenient understanding
- Global attainment for your research
- Manuscript accessibility in different formats
( Pdf, E-pub, Full Text, Audio)
- Unceasing customer service
Track the below URL for one-step submission
https://juniperpublishers.com/online-submission.php

